\title{
SPORE DENSITY AND ROOT COLONIZATION BY ARBUSCULAR MYCORRHIZAL FUNGI IN PRESERVED OR DISTURBED Araucaria angustifolia (Bert.) O. Ktze. ECOSYSTEMS
}

\author{
Milene Moreira ${ }^{1}$; Dilmar Baretta²; Siu Mui Tsai ${ }^{3}$ E Elke Jurandy Bran Nogueira Cardoso ${ }^{4 *}$ \\ ${ }^{1}$ IAC - Centro de Pesquisa e Desenvolvimento de Solos e Recursos Ambientais, Av. Barão de Itapura, 1.481 - \\ 13001-970 - Campinas, SP - Brasil. \\ ${ }_{3}^{2}$ Programa de Pós - Graduação em Solos e Nutrição de Plantas. \\ ${ }^{3}$ USP/CENA - Lab. de Microbiologia e Biologia Molecular, Av. Centenário, 303 - 13416-000 - Piracicaba, SP - \\ Brasil. \\ ${ }^{4}$ USP/ESALQ - Depto. de Ciência do Solo, C.P. 9 -13418-900 - Piracicaba, SP - Brasil. \\ *Corresponding author <ejbncard@esalq.usp.br>
}

ABSTRACT: Araucaria angustifolia (Bert.) O. Ktze., a native forest tree from Brazil, is under extinction risk. This tree depends on arbuscular mycorrhizal fungi for growth and development, especially in tropical low-P soils but, despite being a conifer, Araucaria does not form ectomycorrhiza, but only the arbuscular endomycorrhiza. This study aimed at surveying data on the spore density and root colonization (CR) by arbuscular mycorrhizal fungi (AMF) in Araucaria angustifolia forest ecosystems, in order to discriminate natural, implemented, and anthropic action-impacted ecosystems, by means of Canonical Discriminant Analysis (CDA). Three ecosystems representative of the Campos do Jordão (SP, Brazil) region were selected: 1. a native forest (FN); 2. a replanted Araucaria forest (R); and 3. a replanted Araucaria forest, submitted to accidental fire (RF). Rhizosphere soil and roots were sampled in May and October, 2002, for root colonization, AMF identification, and spores counts. Root percent colonization rates at first collection date were relatively low and did not differ amongst ecosystems. At the second period, FN presented higher colonization than the other two areas, with much higher figures than during the first period, for all areas. Spore density was lower in FN than in the other areas. A total of 26 AMF species were identified. The percent root colonization and spore numbers were inversely related to each other in all ecosystems. $\mathrm{CDA}$ indicated that there is spatial distinction among the three ecosystems in regard to the evaluated parameters.

Key words: Brazil pine, biodiversity, species richness, reforestation

\section{DENSIDADE DE ESPOROS E COLONIZAÇÃO RADICULAR POR FUNGOS MICORRÍZICOS ARBUSCULARES EM ECOSSISTEMAS DE Araucaria angustifolia (Bert.) O. Ktze. PRESERVADOS E IMPACTADOS}

RESUMO: A Araucaria angustifolia (Bert.) O. Ktze. é uma espécie florestal nativa do Brasil e encontrase ameaçada de extinção. É altamente dependente de fungos micorrízicos arbusculares para seu desenvolvimento, principalmente em solos com baixos teores de fósforo. Embora sendo uma conífera, esta árvore não forma ectomicorriza, mas sim a endomicorriza arbuscular. O presente estudo teve como objetivo levantar dados sobre a densidade de esporos e a colonização radicular de fungos micorrízicos arbusculares (FMAs) em ecossistemas florestais de Araucaria angustifolia, visando discriminar os ecossistemas natural, implantado e impactado pela ação antrópica, através da Análise Canônica Discriminante (ACD). Foram selecionados três ecossistemas representativos da região de Campos do Jordão (SP): 1. floresta nativa (FN); 2. floresta replantada de araucária (R); e 3. floresta replantada de araucária, submetida a uma queima acidental (RF). As coletas de solo rizosférico e de raízes foram realizadas em maio e outubro de 2002. Determinaram-se a densidade de esporos, taxa de colonização radicular e identificaram-se os gêneros de FMAs presentes. O número de esporos na FN foi sempre inferior aos reflorestamentos. Foram identificadas ao todo 26 espécies de FMAs. A colonização radicular na primeira coleta apresentou valores os quais não diferiram entre as três áreas estudadas. Entretanto, na segunda coleta, a FN apresentou plantas com maior valor de colonização que aquelas dos reflorestamentos, sendo 
todos os valores superiores aos encontrados na primeira coleta. Houve uma relação inversa entre colonização e número de esporos em todas as áreas. Ocorreu uma separação espacial entre as três áreas de estudo, baseada em análise canônica discriminante das variáveis estudadas.

Palavras-chaves: pinheiro brasileiro, biodiversidade, riqueza de espécies, reflorestamento

\section{INTRODUCTION}

Araucaria angustifolia (Bertoloni) Otto Kuntze is a Gymnosperm tree from the family Araucariaceae. In Brazil its occurrence is mostly restricted to the Southern States Rio Grande do Sul, Santa Catarina and Paraná, including some sparse spots in the States São Paulo, Minas Gerais and Rio de Janeiro (Hueck, 1972), and a few other countries in Southern South America. Such forests are highly endangered of extinction (Brazil, 1992), since they have been systematically clean cut because of the economical value, related to the high quality of the wood. Little is known about the diversity of microorganisms associated to those ecosystems, but a few reports on the occurrence of arbuscular mycorrhizal fungi (AMF) in association with Araucaria (Milanez \& Monteiro, 1950; Oliveira \& Ventura, 1952, Bononi et al., 1989). Muchovej et al. (1992) tested AMF and some ectomycorrhizal isolates, but no growth responses were detected. However, it has been shown that this plant produces arbuscular mycorrhizae and is very dependent on AMF, especially in low-P conditions (Moreira-Souza \& Cardoso, 2002), and descriptions of associated AMF species as well as of colonization patterns were reported (Breuninger et al., 2000; Moreira-Souza et al., 2003).

To preserve Araucaria forests and to maintain the sustainability of a few remnants and reforested areas, it is necessary developing new technologies for seedling inoculation with AM fungi in nurseries. It is herein hypothesized that Araucaria ecosystems under high anthropic impact, and especially after burning, might present a modified AMF community, which may cause decreased biodiversity, root colonization and sporulation. Therefore, the objective of the present study was to survey data on these three parameters in A. angustifolia forest ecosystems, in the aim to discriminate natural, implemented, and anthropic actionimpacted ecosystems.

\section{MATERIAL AND METHODS}

\section{Study sites, treatments, and experimental design}

The collection sites were in native forest and replanted $A$. angustifolia (Bert.) O. Ktze areas. Three sub-areas were selected at Parque Estadual de Campos do Jordão (PECJ) (Campos do Jordão State Park) ( $22^{\circ} 44^{\prime} \mathrm{S}$ and $45^{\circ} 30^{\prime} \mathrm{W}$; altitude about $1700 \mathrm{~m}$ ), State of São Paulo, Brazil. The local climate is Cfb (Köppen classification), characterized as subtropical (upland), mesothermal, and humid. The mean annual precipitation is $1,804 \mathrm{~mm}$, and the mean temperature ranges from $17.5^{\circ} \mathrm{C}$ in the hottest month (February) to $11.5^{\circ} \mathrm{C}$ in the coldest month (June), with the possibility of occurrence of below-freezing temperatures. In May (autumn, cool and dry), maximum temperature was $23.2^{\circ} \mathrm{C}$ and the lowest only $0.9^{\circ} \mathrm{C}$. In October (spring, warmer and rainy), maximum temperature was $35.1^{\circ} \mathrm{C}$ and the lowest $5.2^{\circ} \mathrm{C}$.

Each selected ecosystem was represented by one plot ( $0.5 \mathrm{ha}$ ) where five Araucaria trees were randomly selected, and three equidistant sampling points were determined below the tree top, for each tree. The experimental design was a completely randomized layout, with 15 replicates, involving the following ecosystems: 1 . a native, climax forest with predominance of Araucaria trees (approximately 100 year-old trees), without anthropic interference (FN); 2. an Araucaria forest introduced in 1959 (R); and 3. an Araucaria forest introduced in 1958, submitted to accidental fire in July, 2001 (RF).

The FN basically consists of $A$. angustifolia and other shrubby, herbaceous, and arboreal species belonging to the families Clethraceae, Cunnoniaceae, Lauraceae, Melastomataceae, Podocarpaceae, Rosaceae, Symplocaceae, Myrsinaceae, and Euphorbiaceae. The reforested R area is situated close to FN and presents a similar floristic composition, while the RF forest presents mostly grass in its understore, especially Aristidia longiseta and Baccharis trimera. The FN and R soils are clayey-textured Typic Hapludoxes, and the RF soil is a clayey-textured Typic Dystrochept (Table 1), with similar toposequences, elevations, and geographical positions in the three ecosystems.

\section{Soil and root sampling}

Soil in the root zone (500 g) and Araucaria roots were sampled in the months of May and October, 2002. Samples were collected from 15 points at 0-20 cm depth, at the crown projection area, and $2 \mathrm{~m}$ away from the tree trunk (three points per plant). The soil samples were placed in plastic bags for later determination of number of spores and respective identification. The roots were preserved in $70 \%$ ethyl alcohol until processed. Each sampling point was analyzed separately, to determine total number of spores in $100 \mathrm{~g}$ of dry soil. Sub-samples were removed to assess soil physical and chemical characteristics. 
Table 1 - Chemical and physical soil characteristics in natural (FN), introduced (R), and impacted-by-fire (RF) Araucaria angustifolia ecosystems. Campos do Jordão, SP, Brazil, May 2002.

\begin{tabular}{|c|c|c|c|c|c|c|c|c|c|c|}
\hline \multirow{2}{*}{ Ecosystems } & \multicolumn{7}{|c|}{ Chemical characteristics } & \multicolumn{3}{|c|}{ Physical characteristics } \\
\hline & $\mathrm{pH} \mathrm{CaCl}{ }_{2}$ & $\mathrm{OM}$ & $\mathrm{P}($ resin $)$ & $\mathrm{K}$ & $\mathrm{Ca}$ & $\mathrm{Mg}$ & $\mathrm{H}+\mathrm{Al}$ & Sand & Silt & Clay \\
\hline & $0.01 \mathrm{~mol} \mathrm{~L}^{-1}$ & $\mathrm{G} \mathrm{dm}^{-3}$ & $\mathrm{mg} \mathrm{dm}^{-3}$ & \multicolumn{4}{|c|}{ - mmolc $\mathrm{dm}^{-3}$} & \multicolumn{3}{|c|}{ - } \\
\hline FN & 3.7 & 128 & 13 & 3.7 & 19 & 17 & 228 & 540 & 40 & 420 \\
\hline $\mathrm{R}$ & 3.2 & 88 & 10 & 2.3 & 2 & 4 & 347 & 510 & 180 & 310 \\
\hline RF & 3.1 & 65 & 8 & 2.8 & 1 & 2 & 281 & 570 & 60 & 370 \\
\hline
\end{tabular}

$\mathrm{OM}=$ organic matter; mmolc $=$ milimols, charge-equivalent.

\section{Root colonization (RC), number of spores (NS), di- versity indices and statistical analysis}

To determine root percentage colonization, the roots were cleared in $10 \% \mathrm{KOH}$ and $10 \% \mathrm{H}_{2} \mathrm{O}_{2}$, and stained with pen blue ink and acetic acid (Vierheilig et al., 1998). The presence of fungal structures within the roots was verified by a method that used root segments mounted on slides and observed under the microscope (400×) (Giovannetti \& Mosse, 1980). Eight slides were mounted for each sampled point, containing ten $1 \mathrm{~cm}$-long root segments each.

The number of AMF spores was determined by wet sieving (Gerdemann \& Nicolson, 1963), based on a $100 \mathrm{~g}$ soil aliquot for each studied point, followed by centrifugation in sucrose (Jenkins, 1964). The spores were counted under a stereoscopic microscope (40X), and identification was made to the species level using an optical microscope (100 to 400X), with the aid of the Schenck \& Pérez (1990) manual, and descriptions provided by the site of International Collection of Vesicular and Arbuscular Mycorrhizal Fungi (http:// invam.caf.wvu.edu) and the original species descriptions.

Additionally, the ecological aspects were estimated in the following manner: species richness (R), evaluated by the number of arbuscular mycorrhizal fungal species (NS) present in $100 \mathrm{~g}$ of dried soil, Simpson's dominance index (Is), and Shannon's diversity index (H), according to Odum (1983). The NS, R, $\mathrm{Is}$, and $\mathrm{H}$ data were also submitted to multivariate $\mathrm{Ca}$ nonical Discriminant Analysis (CDA), using the SAS version 6.2 statistical software (SAS Institute, 1996). After CDA, calculations were made for homogenized canonical coefficients (HCC), coefficient of correlation $(r)$, and parallel discrimination rate coefficient (PDRC $=r \times \mathrm{HCC})$, and means were compared by the LSD test $(P<0.05)$, according to Cruz-Castillo et al. (1994), in the aim to identify which ecological attribute has a greater weight in detecting differences in ecosystems.

\section{RESULTS AND DISCUSSION}

With regard to root colonization, all $A$. angustifolia root segments analyzed were colonized by
AMF, with the occurrence of hyphae, vesicles, arbuscules, and auxiliary cells, both internally and/or in association with the roots. These results were similar to those found by Breuninger et al. (2000) and Moreira-Souza et al. (2003).

In the first sampling (May), no root colonization (RC) differences among the three ecosystems (FN, $\mathrm{R}$ and RF) were registered. Low RC was observed in all studied areas, ranging from 10.7 to $14.5 \%$ (Figure 1A). Surveying native and reforested areas in the same region Moreira-Souza et al. (2003) found rates of 21 to $29 \%$ for native forest and 14 to $18 \%$ in reforested areas, somewhat higher than those referred here. In the $\mathrm{FN}$, colonization was characterized by the presence of many external and thick hyphae, with thickened hyphal tips, and also many spores inside the roots, with frequent presence of auxiliary cells, perhaps denoting greater predominance of Gigasporaceae. In the $\mathrm{R}$ and RF replantings, hyphae were mostly very thin and continuous, probably a pertinent fact especially for Glomaceae and Acaulosporaceae.

In the second sampling (October), increased RC was registered for all areas (25- 40\%); the FN roots showed more than twice the RC observed in the first sampling for the same Araucaria plants (Figure 1A). $\mathrm{RC}$ values recorded for replanted areas ( $\mathrm{R}$ and $\mathrm{RF}$ ) were lower than in the FN; however, they were also much higher than in the first collection. RC values for RF did not differ from $\mathrm{R}$, at the same sampling periods. On the other hand, since these data were obtained about one year after the accidental burning, it is possible, that enough time had elapsed for the recuperation of this ecosystem. Also, since AMF are soilborne, it would not be expected a light fire to cause strong, direct impacts on this segment. The impacts probably would be indirect, to the same degree as the physiology of the burned Araucaria trees had been affected.

Rainfall was lower than expected for both sampling periods: $38 \mathrm{~mm}$ in May and $78 \mathrm{~mm}$ in October; temperature was lower in May $\left(0.9^{\circ} \mathrm{C}-23.2^{\circ} \mathrm{C}\right)$ and higher in October $\left(5.2^{\circ} \mathrm{C}-35.1^{\circ} \mathrm{C}\right)$. The climatic factors probably affected spore number as well as root colonization. During cool and dry weather, root colo- 
nization was low, but sporulation was relatively high; the opposite occurred at the warm season, with more root colonization and fewer spores. It has been reported that root colonization ordinarily increases until $35^{\circ} \mathrm{C}$ (Bowen, 1987). This finding could not be confirmed here.

The number of AMF spores (NS) recorded during the October sampling was lower than in May, and a lower number of spores was found in the FN area in comparison to R and RF ecosystems (Figure 1B). At both periods and for all three ecosystems, whenever sporulation was high, the root colonization rate was low, and vice-versa (Figures 1A and 1B). In perennial plants, there may be a greater influence of the physiological and phenological stage of the host plant on sporulation. Certain stress situations might elicit a stimulus for greater spore production, which could be important for the survival of the endophyte. This could have been the case in the three studied ecosystems, and would also explain the lower spore numbers in the native, well preserved ecosystem.

Thus, AMF sporulation at the same sampling point is very dynamic in relation to different seasons of the year, that is, numbers of spores are not always

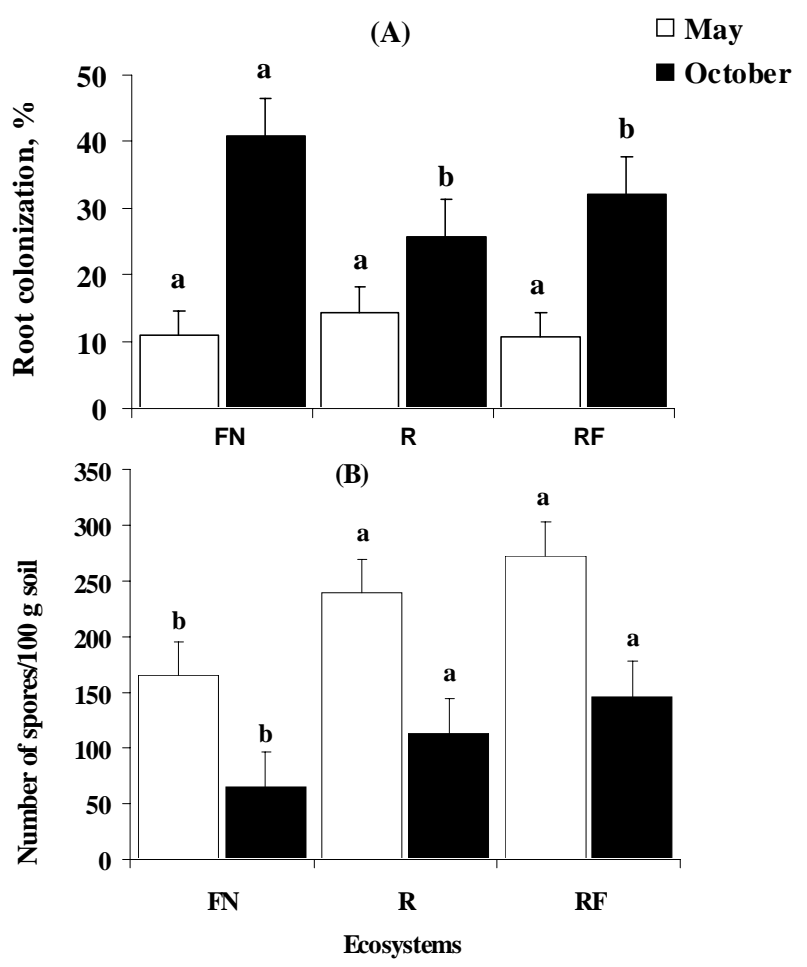

Figure 1 - Root colonization rate by arbuscular mycorrhizal fungi (A) and Number of spores (B) in natural (FN), introduced (R), and accidental fire-impacted (RF) Araucaria angustifolia ecosystems, in May and October. Mean of 15 replicates. ( $T$ ) Standard deviation. Means followed by the same letters on columns do not differ $(P<0.05)$ by the LSD test. reliable parameters to determine the composition of the AMF community in an ecosystem. There are fungi that sporulate more, while others sporulate less (perhaps never), and others yet, only sporulate during certain periods of the year. Sampling sites several times throughout the year is indispensable. Moreira-Souza et al. (2003) observed that number of spores was much higher in the same localities. Breuninger et al. (2000) also studied AMF sporulation in Araucaria forests in southern Brazil, and reported higher number of spores and root colonization than that recorded in the present work. Although the spore counts were generally low, richness indices were similar to those determined previously by these two authors.

There is accumulated, growing evidence on the difficulty of making generalizations about infection patterns in AM fungi. Variability can be extreme, since these parameters are influenced by factors inherent to the host plant, by climatic and edaphic factors, by effects of the soil community and by the interactions of all of these. Although root colonization and sporulation seem to be correlated, at least in some cases, with plant phenology and physiology (Escudero \& Mendonza, 2005), it has also been shown that the community of AM fungi may determine host plant community's association and production (Van der Heijden et al., 1998). On the other hand, Bever et al. (1996) and Bever (2002) demonstrated that each endophyte may be multiplied quite differently on different host plants, and that there may be positive as well as negative feedback occurring between specific host plants and their endophytes.

Considering both sampling periods (May and October), 26 species of AM fungi, with a total of 1099 spores (data not shown) were registered. This is a very high diversity for AMF, which agrees with data of Sieverding (1991), who described the occurrence of 25 to 30 species in natural ecosystems. However, Schenck \& Siqueira (1987) described only 16 species in natural areas in Brazil. In this study, the AMF were distributed in five genera, with 10 species of Acaulospora, one of Entrophospora, four of Gigaspora, five of Glomus, and six of Scutellospora species. Gigaspora decipiens and Scutellospora pellucida were observed only in the FN ecosystem in May. Scutellospora heterogama and Gigaspora decipiens were present only in May or, respectively, only in October, in the FN ecosystem, while Gigaspora gigantea spores appeared only in October, in FN and R. These Gigasporaceae species were not observed in the RF ecosystem, while the genera Acaulospora and Glomus are very common in secondary Araucaria forests (Breuninger et al., 2000). 
The number of spores has also been correlated with the phenological stage of the host plant by other authors (Hayman, 1970; Giovannetti, 1985; Bononi et al., 1988; Gemma \& Koske, 1988). Opposed to what happens with the annual plants, perennial plants do not present a definitive final point for root growth. However, they also have a physiological cycle with a dynamic root death and root growth sequence, which results in a somewhat continuous development. It has also been suggested that AMF have different behavior in perennial plants, without a condensed sporulation at the end of the life cycle, as in annuals (Gemma \& Koske, 1988). Baylis (1969) observed a low sporulation number with a more or less even distribution throughout the year and high colonization rates in perennials, when growing in temperate climate. Baylis (1969) and also Sparling \& Tinker (1975) point out that, in this case, there is not any special period, during which a higher stimulus for sporulation occurs. Similar results were obtained in our study. Therefore, the high number of spores in areas of anthropic impact may also be a response of AMF to the physiological impact that the fire caused to the trees, as a reaction to a stress situation and to guarantee higher survival rates. Although several authors (Vilariño \& Arines, 1991; Bellgard et al., 1994; Rashid et al., 1997) found reduction in root colonization and number of spores due to the action of fire, this did not occur in the Araucaria areas.

The canonical discriminating analysis indicated that there are major differences among the three studied ecosystems (Figure 2). The LSD test of the means of the homogenized canonical coefficients (HCC), for FDC1 and FDC2 of all the analyzed variables, also points out that there are significant differences (Table 2). According to PDC1, system R presented the greatest diversity, followed by FN and finally by RF. For FDC2 there was no significant difference between the three ecosystems.

Table 2 - Analysis of variance of the means of the homogenized canonical coefficient (HCC) of the first and second discriminating canonical functions (FDC1 and FDC2), referred to the values of the ecological attributes in natural (FN), introduced (R), and impacted-byaccidental-fire (RF) Araucaria angustifolia ecosystems, in May and October. Mean of 30 replicates.

\begin{tabular}{lcc}
\hline Ecosystems & FDC1 & FDC2 \\
\hline FN & $0.76 \mathrm{~b}$ & $-0.60 \mathrm{a}$ \\
R & $4.03 \mathrm{a}$ & $0.36 \mathrm{a}$ \\
RF & $-4.19 \mathrm{c}$ & $-0.21 \mathrm{a}$ \\
\hline
\end{tabular}

Means followed by the same letter in the columns do not differ $(P<0.05)$ by the LSD test.

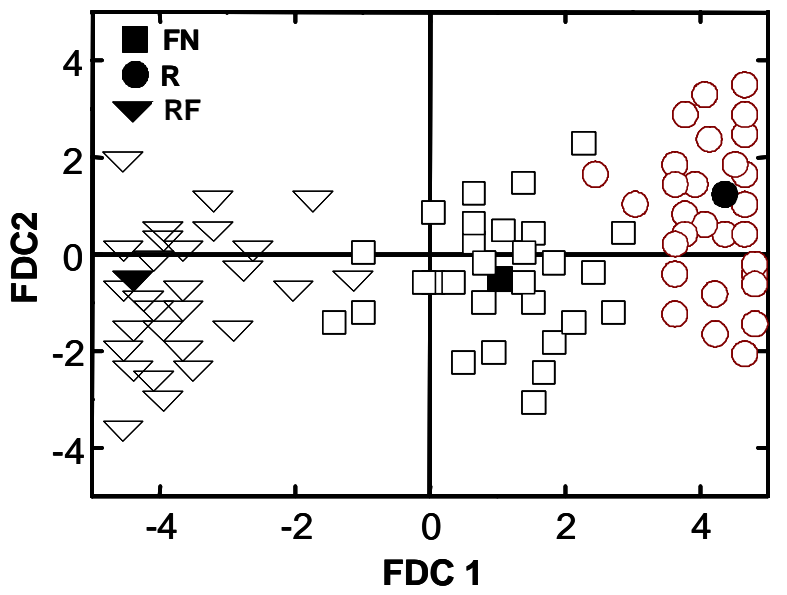

Figure 2 - Relationships between the first and the second discriminating canonical functions (FDC1 and FDC2) on the homogenized canonical coefficient (HCC) for the ecological attributes in natural (FN), introduced (R), and accidental fire-impacted (RF) Araucaria angustifolia ecosystems, in May and October. Mean of 30 replicates. Mean points are represented in black.

\section{ACKNOWLEDGEMENTS}

To FAPESP for granting a post-doctoral scholarship (Process no. 01/13229-9) to M. Moreira and to the financial support of this project (Process no. 01/ 05146-6). To CNPq for a research fellowship to E.J.B.N. Cardoso, S.M. Tsai and D. Baretta. The authors thank the Campos do Jordão State Park and the Environmental Secretary of the State of São Paulo for authorizing the collection of plant material (Process no. 40405/98 COTEC 079/98). To Denise Mescolotti and Luis Fernando Baldesin for technical assistance.

\section{REFERENCES}

BAYLIS, G.T.S. Host treatment and spore production by Endogone. New Zealand Journal of Botany, v.7, p.155-160, 1969.

BELLGARD, S.E.; WHELAN, R.J.; MUSTON, R.M. The impact of wildfire on vesicular-arbuscular mycorrhizal fungi and their potential of influence the re-establisment of post-fire plant communities. Mycorrhiza, v.4, p.139-146, 1994.

BEVER, J.; MORTON, J.; ANTONOVICS, J.; SCHULTZ, P. Hostdependent sporulation and diversity of arbuscular mycorrhizal fungi in a mown grassland. Journal of Ecology, v.84, p.71-82, 1996.

BEVER, J. Host-specificity of AM fungal population growth rates can generate feedback on plant growth. Plant and Soil, v.244, p.281290, 2002.

BONONI, V.L.R.; BARBOSA, L.M.; VIRIATO, A. Micorrizas vesículoarbusculares em amendoim e em plantas invasoras da cultura. Hoehnea, v.15, p.1-9, 1988.

BONONI, V.L.R.; GRANDI, R.A.P.; LOPES, S.A.R.; RODRIGUES, E.; FONSECA, M.P. Micorrizas vesiculo-arbusculares em Araucaria angustifolia (Bert.) O. Ktze. In: REUNIÃO BRASILEIRA SOBRE MICORRIZAS, 3., Piracicaba, 1989. Livro de resumos.

BOWEN, G.D. The biology and physiology of infection and its development. In: SAFIR, G.R. (Ed.) Ecophysiology of mycorrhizal plants. Boca Raton: CRC Press 1987. p.27-70. 
BRASIL. Instituto Brasileiro do Meio Ambiente e dos Recursos Naturais Renováveis. Lista oficial de espécies da flora brasileira ameaçadas de extinção. Portaria IBAMA n.06 N, de 15 de janeiro de 1992. Diário Oficial da União, Brasília, 1992. p.870-872.

BREUNINGER, M.; EINIG W.; MAGEL, E.; CARDOSO, E.; HAMPP, R. Mycorrhiza of Brasil Pine (Araucaria angustifolia Bert. O. Ktze). Plant Biology, v.2, p.4-10, 2000.

CRUZ-CASTILLO, J.G.; GANESHANANDAM, S.; MACKAY, B.R.; LAWES, G.S.; LAWOKO, C.R.O.O.; WOOLLEY, D.J. Applications of canonical discriminant analysis in horticultural research. HortScience, v.29, p.1115-1119, 1994.

ESCUDERO, V.; MENDONZA, R. Seasonal variation of arbuscular mycorrhizal fungi in temperate grasslands along a wide hydrologic gradient. Mycorrhiza, v.15, p.291-299, 2005.

GEMMA, J.K.; KOSKE, R.E. Seasonal variation in spore abundance and dormancy of Gigaspora gigantea and in mycorrhizal inoculum potential of a dune soil. Mycologia, v.80, p.211-216, 1988.

GERDEMANN, J.W.; NICOLSON, T.H. Spores of mycorrhizal Endogone species extracted from soil by wet sieving and decanting. Transactions of the British Mycological Society, v.46, p.235-246, 1963.

GIOVANETTI, M. Seasonal variations of vesicular-arbuscular mycorrhizas and endogonaceous spores in a maritime sand dune. Transactions of the British Mycological Society, v.84, p.679-684, 1985.

GIOVANNETTI, M.; MOSSE, B. An evaluation of techniques for measuring vesicular arbuscular mycorrhizal infection in roots. New Phytologist, v.84, p.489-500, 1980.

HAYMAN, D.S. Endogone spore numbers in soil and vesiculararbuscular mycorrhiza in wheat as influenced by season and soil treatment. Transactions of the British Mycological Society, v.54, p.53-63, 1970.

HUECK, K. As florestas da América do Sul. São Paulo: Polígono, 1972. 466p.

JENKINS, W.R. A rapid centrifugation technique for separating nematodes from soil. Plant Disease Report, v.48, p.692, 1964.

MILANEZ, F.R.; MONTEIRO NETO, H. Nota prévia sobre micorriza no pinho do Paraná. Arquivos do Serviço Florestal, v.4, p.87-93, 1950.

MOREIRA-SOUZA, M.; CARDOSO, E.J.B.N. Dependência micorrízica de Araucaria angustifolia (Bert.) O. Ktze. sob doses de fósforo. Revista Brasileira de Ciência do Solo, v.26, p.905-912, 2002.

MOREIRA-SOUZA, M.; TRUFEM, S.F.B.; GOMES-DA-COSTA, S.M.; CARDOSO, E.J.B.N. Arbuscular mycorrhizal fungi associated with Araucaria angustifolia (Bert.) O. Ktze. Mycorrhiza, v.13, p.211-215, 2003.
MUCHOVEJ, R.M.C.; ALVES, A.C.; MUCHOVEJ, J.J.; KASUYA, M.C.M. Influência da inoculação com fungos ectomicorrízicos e MVA sobre o comportamento de mudas de Araucaria angustifolia (BERT.) O. KTZE. Hoehnea, v.19, p.9-18, 1992.

ODUM, E.P. Ecologia. Rio de Janeiro: Guanabara, 1983. 434p.

OLIVEIRA, M.; VENTURA, A. A ocorrência de micorriza em Araucaria angustifolia (Bert.) O. Ktze e Podocarpus lamberti. São Paulo: Serviço Florestal, 1952, 5p. (Edições e propaganda, 25).

RASHID, A.; AHMED, T.; AYUB, N.; KHAN, A.G. Effect of forest fire on number, viability and post-fire re-establishment of arbuscular mycorrhizae. Mycorrhiza, v.7, p.217-220, 1997.

SAS Institute. SAS/STAT, Release 6.2. Cary: SAS Institute Inc.,1996.

SCHENCK, N.C.; PÉREZ, Y. Manual for the identification of VA mycorrhizal fungi. 3.ed. Gainesville: Synergistic, 1990.

SCHENCK, N.C.; SIQUEIRA, J.O. Ecology of V.A. mycorrhizal fungi in temperate agro-ecosystems. In: SYLVIA, D.M.; HUNG, L.L.; GRAHAM, J.H. (Ed.) Mycorrhizae in the next decade practical applications and research priorities. Gainesville: University of Florida, 1987. p.2-4.

SIEVERDING, E. Vesicular arbuscular mycorrhiza management in tropical agrosystems. Eschborn, Germany: GTZ, 1991. 371p.

SPARLING, G.P.; TINKER, P.B. Mycorrhizas in Pennine grassland. In: SANDERS, F.E; MOSSE, B.; TINKER, P.B. (Ed.) Endomycorrhizas. London: Academic Press, 1975. p.545-560.

VAN DER HEIJDEN, M.G.A.; KLIRONOMOS, J.N.; URSIC, M.; MOUTOGLIS, P.; STREITWOLF-ENGEL, R.; BOLLER, T.; WIEMKEN, A.; SANDERS, I.R. Mycorrhizal fungal diversity determines plant biodiversity, ecosystem variability and productivity. Nature, v.369, p.69-72, 1998.

VIERHEILIG, H.; COUGHLAN, A.P.; WYSS, U.; PICHÉ, Y. Ink and vinegar, a simple staining technique for arbuscular-mycorrhizal fungi. Applied and Environmental Microbiology, v.64, p.5004-5007, 1998.

VILARIÑO, A.; ARINES, J. Numbers and viability of vesiculararbuscular fungal propagules in field soil samples after wild-fire. Soil Biology and Biochemistry, v.23, p.1083-1087, 1991.

Received November 08, 2005

Accepted May 20, 2006 